\title{
Chapter 3 \\ Immobility in Times of Crisis? The Case of Greece
}

\author{
Georgia Mavrodi and Michalis Moutselos
}

Greece, like other countries of Southern Europe, had in the beginning of the twentyfirst century completed a spectacular reversal of its migration history. Starting out as the European country with the most extensive emigration flows relative to its population in the early 1970s, Greece ended up, by the late 2000s, as the EU country with the highest percentage of (legal and estimated illegal) immigrant to national population (Kasimis 2013). Yet the severe economic crisis that started in 2008 challenges this remarkable development. Could the swing of the historical pendulum once again have more people migrating out of the country? Indeed the country's economic woes have reversed the balance of migratory flows. Repatriation of immigrants who resided in Greece has been much more dramatic than new emigration, the latter consisting mostly of high-skilled workers. Greek policymakers have so far not developed a coherent policy vis-à-vis these developments, while existing networks and institutional frameworks, many of which are a legacy of the post-war migration, have not adapted to the recent waves.

\subsection{Socio-economic Situation in Greece}

Greece is, without doubt, the Eurozone member-state hit most severely by the economic crisis. The country's economy was in recession between 2008 and late 2014 . Its real GDP growth rate fell dramatically during four consecutive years (20082011) peaking at a spectacular if devastating 7.1\% drop in 2011. In the year 2013 real GDP growth continued to fall by $3.9 \%$ (Eurostat 2014). Overall, almost $25 \%$

\author{
G. Mavrodi $(\square)$ \\ European University Institute, Florence, Italy \\ e-mail: georgia.mavrodi@eui.edu \\ M. Moutselos \\ Princeton University, Princeton, NJ, USA
}


Table 3.1 Real GDP growth rate and GDP per capita in PPS, 2007-2014

\begin{tabular}{l|l|l|l|l|l|l|l|l}
\hline & 2007 & 2008 & 2009 & 2010 & 2011 & 2012 & 2013 & 2014 \\
\hline Real GDP growth rate & $3.5 \%$ & $-0.2 \%$ & $-3.1 \%$ & $-4.9 \%$ & $-7.1 \%$ & $-7.0 \%$ & $-3.9 \%$ & $0.8 \%$ \\
\hline $\begin{array}{l}\text { GDP/capita in PPS (EU28 } \\
=100 \text { ) }\end{array}$ & 91 & 93 & 94 & 87 & 77 & 74 & 73 & 72 \\
\hline
\end{tabular}

Source: Eurostat $(2015 \mathrm{a}, \mathrm{b})$

losses of its GDP between and relative per capita income occurred between 2009 and 2013 (Table 3.1).

At the same time there is a decline in the population residing in the country. After years of a continuous population rise, owing much to international immigration, on 1 January 2009 the country had reached a peak at 11,190,654 inhabitants. Two years later they were reduced to $11,123,392$. It is estimated that the total population had fallen below eleven million as of 1 January 2014 (10,926,807 inhabitants), at about the same level as in the late 1990s, with another 100,000 estimated to have left the country by January 2015 (Eurostat 2015c).

Heavy recession has gone hand-in-hand with steady, uninterrupted increase in unemployment rates that began in early 2009. At that time, the number of long-term unemployed (defined as those actively seeking employment for 12 consecutive months or longer) surpassed 300,000 people, reaching 381,642 in December 2009, 474,745 in September 2010, and 611,785 in March 2011. Short-term unemployment also increased considerably, from 138,284 people in March 2010 to 180,817 people a year later albeit recording lower numbers during the summer months. During the first trimester of 2014, over 1,355,000 people were officially recorded as unemployed among a total population of approximately 11 million, with a slight decrease noted in the first trimester of 2015 (ELSTAT 2014, 2015).

How unemployment relates to the economic crisis can be traced by taking into account the official unemployment data recorded during the first trimester of each year since 1998. We choose to look at the first trimester (January-March) of each year to account for seasonal unemployment in important economic sectors such as tourism, agriculture, and constructions.

According to Greek official statistics, unemployment rose from $9.3 \%$ in 2009 to $27.8 \%$ in 2014 (ELSTAT 2009, 2010, 2011, 2012, 2014, 2015). It would be misleading to simply attribute high unemployment rates in 2009 to the outbreak of the economic crisis. During the previous decade, with the exception of 2007 and 2008, unemployment had been relatively high and, despite economic growth, unemployment rates had peaked in the first trimesters of 1999 and 2000 at $12.2 \%$ and $12.3 \%$, respectively. However, the first 2 years of crisis put a halt to the gradual but significant reduction of unemployment achieved between 2004 and 2008 (from $11.3 \%$ to $8.2 \%$ during the first trimester of those years, respectively) and introduce a period of unprecedented and precipitous rise ever since (ELSTAT 2009, 2010) (Table 3.2).

Apart from the loss of hundreds of thousands of jobs, the crisis has altered the geographical distribution of unemployment and strategies of job-seekers. For instance, those without a job today are much less selective than their counterparts 


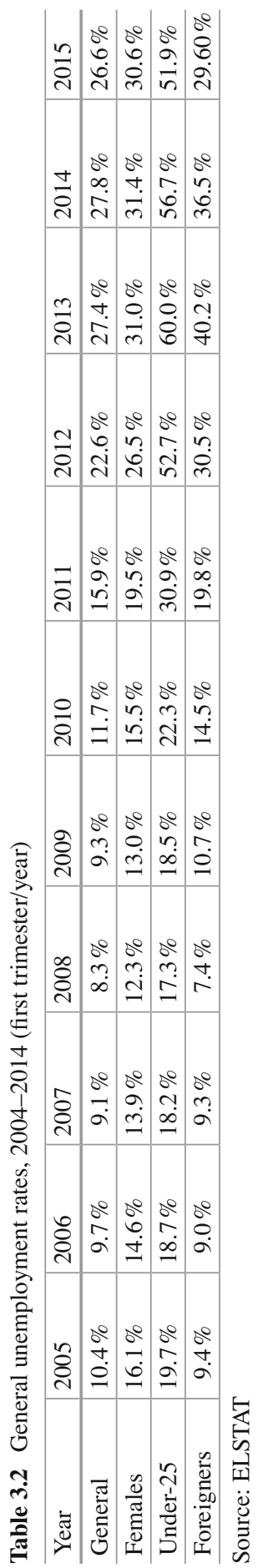


5 years ago: whereas $11.1 \%$ of the unemployed in early 2009 had refused at least one job offer for various reasons, those in early 2014 who did the same were only $4 \%$ (Ibid.). The share of part-time work in overall employment has also increased gradually, from $6.1 \%$ in early 2009 to $9.5 \%$ in early 2015 . More significant are the changes in qualitative characteristics of employment. In early $2015,68 \%$ of parttime employees had this type of employment because they could not find a full-time job, as opposed to $45.9 \% 6$ years before. Moreover, in addition to geographical areas known for high unemployment rates prior to the crisis (such as western Macedonia in Northern Greece), regions that previously attracted internal and international migrants for employment purposes (such as Attica and Crete) are now hit particularly hard (Table 3.3).

Within this wider framework of change some structural characteristics of unemployment in Greece have remained constant. Unemployment continues to affect predominantly the young, women and the low-skilled. Women aged 24 and below have most difficulties to find a job (in the last 3 years, over $55 \%$ of this category have been unemployed) while men with a degree of tertiary education have been the most likely to be employed. Paradoxically, those with primary education had and still have better chances in the Greek labour market than those with secondary education or the holders of a degree of tertiary technical education (ELSTAT 2009, 2010, 2012, 2013a, b, 2014, 2015). Last but not least, as Table 3.2 suggests, the crisis disproportionately affected foreign workers, a group that had exhibited lower unemployment rates than the national average, but whose unemployment level increased more than fivefold between 2008 and 2013.

The recession also resulted in the significant reduction of disposable income for individuals and households, increasing poverty, and social exclusion. According to Eurostat, the median net income declined from 11,963 euros in 2010 to 7714 euros in 2014 while the mean net income decreased from 13,974 euros to 8879 euros during the same period $(-35.5 \%$ and $-36,4 \%$, respectively) (Eurostat $2015 \mathrm{~d}$ ). According to more precise estimates covering part of this period, relative poverty (defined as the percentage of the general population with an income that lies below $60 \%$ of the median disposable income) showed a modest increase, from $19.4 \%$ in 2009 to $22.3 \%$ in 2013 (Matsaganis and Leventi 2013: 3). However, there is great variation among different population categories.

Table 3.3 Unemployment in selected Greek regions, 2009-2014 (first trimester)

\begin{tabular}{|c|c|c|c|c|c|c|c|}
\hline \multirow[b]{2}{*}{ Region } & \multicolumn{7}{|l|}{ Year } \\
\hline & 2009 & 2010 & 2011 & 2012 & 2013 & 2014 & 2015 \\
\hline Attica & $7.6 \%$ & $10.7 \%$ & $14.7 \%$ & $22.9 \%$ & $28.6 \%$ & $28 \%$ & $26.7 \%$ \\
\hline Crete & $10.9 \%$ & $12.9 \%$ & $15.7 \%$ & $23.4 \%$ & $26.9 \%$ & $26.9 \%$ & $27.2 \%$ \\
\hline Western Macedonia & $14.4 \%$ & $15.1 \%$ & $22.3 \%$ & $28.5 \%$ & $32.0 \%$ & $28.4 \%$ & $29 \%$ \\
\hline Ionian islands & $14.1 \%$ & $20.4 \%$ & $20.3 \%$ & $15.9 \%$ & $22.8 \%$ & $27.4 \%$ & $28.9 \%$ \\
\hline Southern Aegean & $16.9 \%$ & $18.9 \%$ & $24.3 \%$ & $13.9 \%$ & $24.9 \%$ & $30.3 \%$ & $25.4 \%$ \\
\hline
\end{tabular}

Source: ELSTAT (2009, 2011, 2012, 2014, 2015) 
Between 2009 and 2013, relative poverty increased most sharply for the unemployed (from 34.2 to $46.7 \%$ ), for households residing in rented property or paying home mortgage (from 19.3 to $27.2 \%$ ), for the self-employed (from 17.3 to $24.0 \%$ ), and for those residing in Athens, as opposed to other urban or rural areas (from 16.1 to $24.7 \%$ ) (Matsaganis and Leventi 2013: 3). Moreover, over 60\% of the unemployed adults were in danger of social exclusion in 2010, 2011 and 2012 (Karakitsios 2014: 10). In contrast, relative poverty has been negligible for civil servants and bank employees; it has been low and declining for some professional groups (private doctors, lawyers, engineers and mass media employees); it has slightly increased for paid employees in the private sector and students (1.5 and $3.2 \%$ increase, respectively); and, albeit high, it showed a sharp decrease for those employed in agriculture (from $34.1 \%$ in 2009 to $24 \%$ in 2013). Finally, among generational categories, young adults up to 29 years have been subject to the sharpest increase in relative poverty (from $19.5 \%$ in 2009 to $26.9 \%$ in 2013 ), the reverse of pensioners and the elderly (Matsaganis and Leventi 2013: Ibid.).

These estimates reveal a mixed picture. While the Greek recession has been continuous and severe, parts of the population have remained more protected (civil servants who have retained their positions albeit with reduced salaries, free professionals and, to a significant degree, pensioners) while others (such as the unemployed, the young and the self-employed) have experienced growing relative deprivation and/or poverty. Even when income in 2013 is compared with a stable poverty limit, namely the adjusted poverty level of the year 2009, the unemployed, the self-employed and the young appear as the main victims of the crisis (Matsaganis and Leventi 2013: 4-5). These developments relate to long-established structural characteristics and redistributive consequences of the Greek system of social protection, along with the effects of austerity on public finances and programs of social security (Matsaganis 2013: 2).

The latter continued to protect the rights and income of parts of the population directly or indirectly supported by the state (civil servants, employees in public utility companies and pensioners) much more than the unemployed, the paid employees in the private sector, and the self-employed. For decades, this social welfare model - at the same time discriminatory, selective and weak - was coupled by the protective and supportive role of traditional social networks (most importantly the family) towards the young, the elderly and those in need, characterised by the provision of both material and non-material support to the most vulnerable (Htouris 2012; see also Eurostat 2013a for data on income pooling and sharing within the household). Increasing unemployment and cuts in earnings and wages have put strains on the ability of households and families to fully perform this function.

The recession has most severely hit parts of the population with low levels of human capital (Zografakis and Mitrakos 2012). The latter include single-parent families, the long-term unemployed, and the country's immigrant population, especially third-country nationals (largely employed in the private sector and in lowpaid seasonal economic activities) who have largely remained outside the coverage of the basic social security net (Matsaganis 2013; Zografakis and Mitrakos 2012; Balourdos 2012). It has been estimated that Albanian immigrant households have 
faced the greatest danger of falling to low-income-earner status, compared to both Greek households and immigrant households of other nationalities (Zografakis and Mitrakos 2012). The less favourable employment situation for third-country nationals is not a Greek phenomenon and has been noted in labour markets across the EU. In particular, along with the existence of looser ties with the host country, the employment of third-country nationals in jobs with fixed-term contracts and in economic sectors with high sensitivity to the business cycle (such as tourism and construction) is connected with higher labour mobility and employment volatility.

\subsection{Migratory Dynamics and Volume of Emigration Flows}

The period between 1955 and 1977 marked the most extensive wave of outward migration, with about 1.2 million people moving out of Greece, roughly half to Germany, 30,000 to Belgium and about 370,000 overseas, mostly in the United States, Canada and Australia. The reasons for emigration were primarily economic and the rural areas of Epirus, Macedonia and Thrace in the North were particularly overrepresented during the post-war wave. In addition, about 65,000 political refugees had fled the country after the Greek Civil War after 1949, but the majority of them relocated to countries of the former Eastern Bloc. After 1970 there was a counter-wave of repatriation, particularly from European countries, towards Greek urban centers (Glytsos and Katseli 2005).

It is notable that data for post-war emigration are more informative than currently available data collected by the Greek authorities. The scarcity of detailed information poses a major challenge to the description, analysis and understanding of the phenomenon - a problem not limited to the Greek case, as the difficulty in collecting systematic data partly relates to the free movement of people among EU member-states (Deutsche Bank Research 2011: 5).

The Greek national statistical agency (ELSTAT) focuses on recording the number of foreign nationals entering or residing in the country. Additional estimates of emigration flows and their publication, a practice that began in 2010, do not include Greek citizens. Moreover, the issue of current migration movements from Southern EU member-states to the rest of the EU is under-researched, fuelled by nonregistration of recent emigrants with the authorities of their countries of origin (Triandafyllidou and Gropas 2014). As a result, best available data are those released by national statistical agencies in the countries of destination, as well as larger databases and publications by international organisations.

According to Eurostat (2013b), outflows from Greece began outnumbering inflows in 2008, when Greece recorded negative net migration for the first time since 1998 (the first year of publication of such data). Between 2009 and 2012, emigration increased rapidly. Outflows peaked in 2010 followed by a drop in 2011, only to resume strength in 2012. The timing of the increase in net migration outflows corresponds to the outbreak of the economic crisis. The figures also include foreign citizens, including non-EU citizens, who had settled in Greece in the 1990s 
and 2000s. Indeed, most recent work on emigration from Italy highlights the exodus of EU citizens and third-country nationals (Triandafyllidou and Gropas 2014: 2).

According to the OECD, the number of registered foreign (non-EU) citizens in Greece fell from 610,800 in 2009 to 507,000 in 2012 (OECD 2015). This development may reflect a large-scale departure of Albanian nationals, who had been the dominant immigrant group in Greece since the early 1990s. In fact, according to the estimates of the Albanian Institute of Statistics about 95,000 Albanians of 18 years old and above returned from Greece to Albania between 2009 and 2013 (INSTAT and IOM 2014). In contrast, emigration of Greek nationals appears to be limited (OECD 2013: 258). This is not to say that Greeks are not part of the wider phenomenon of new migrations from the European South to Northern Europe and beyond. According to the OECD, significant percentage increases in new arrivals of Greek citizens have been recorded in Germany, the United Kingdom, the Netherlands and Sweden. Over 30,000 people left Greece for these countries in 2011 while in 2012 there were over 40,000 Greek nationals arriving in Germany and Sweden alone (OECD 2013: 256, 258).

National statistics, when available in the countries of destination, offer a more detailed picture. A direct comparison among them is often difficult, given the different time frames and categories used (citizenship, country of birth, point of departure) The most recent provisional immigration data from Germany indicates that 31,861 persons arrived from Greece in 2014, 30,602 of whom were non-German citizens. These figures made Greece the 11th most important country of origin of new immigrants, despite a slight decrease when compared to previous years (a total of 35,811 persons in 2012 and 34,728 persons in 2013). At the same time, a total of 17,225 persons emigrated from Germany to Greece (Statistisches Bundesamt 2014).

A clearer picture is provided by data reflecting the immigration trend of nonGerman citizens from Greece in the last decade. After 5 years of stability (between 8000 and 9000 persons each year in the period 2005-2009, greatly outnumbered by an average of 15,000 non-German citizens emigrating from Germany to Greece per year, new arrivals increased dramatically in 2011 (12,523 persons) and 2012 (23,779 persons), before peaking at 33,739 persons in 2013 and falling slightly to 30,602 persons in 2014. At the same time, it seems that the outbreak of the severe economic crisis discouraged Greeks already residing in Germany from returning back: compared to 14,841 non-German citizens who emigrated to Greece in 2009, 11,482 chose to do so in 2010, followed by 10,306 in 2011 (Statistisches Bundesamt 2014: 19-20). Yet, a modest increase in the number of those leaving to Greece since 2012 may indicate a reversal of this trend, possibly related to the stabilisation of the economic situation in Greece or the limited return of retired past economic migrants.

The upward trend of arrivals from Greece can also be detected in the United Kingdom, at a faster pace, albeit at a smaller scale. According to annual estimates of the Office of National Statistics - reporting foreign-born and foreigners -, estimated arrivals of those born in Greece for the period 2006-2014 peaked in 2011 and 2012 (about 8000 new arrivals), slightly upwards from 6000 arrivals in 2007 and went back to 6000 in 2013 and 2014. These inflows are typical of the entire period since the early 2000s reflecting a strong preference among Greek youth for the UK 
as a place of study and employment. The most remarkable development is the slowdown of return migration from the UK to Greece that has caused the number of UK residents born in Greece to swell from about 25,000 in 2007 to about 52,000 in 2014. Similar trends can be found in the estimated numbers of Greek nationals residing in the UK with 54,000 residents in 2012 compared to 26,000 in 2007 (see also UK chapter) (Office of National Statistics 2015).

In the Netherlands, the total number of residents of Greek origin shows a steady and significant increase in the last 6 years (from 13,888 persons in 2009 to 15,052 in 2011 , to 18,253 in 2013 and 19,217 in 2014). Only 599 persons among them belong to the second generation whereas 4724 are newcomers (CBS 2014). Increases in arrivals of Greek citizens are also recorded in other member-states but they start from a very low base and the total number is rather insignificant. In Austria, for instance, the number of Greek citizens arriving in the country between 2010 and 2012 increased twofold: 519 persons in 2010, followed by 813 in 2011 and 1201 in 2012 (Statistik Austria 2013: 28). In Belgium, 14,922 Greek residents were recorded on January 1st, 2009 and 14,798 a year later, while the number increased to 16,275 by January 1st 2015 (Statistics Belgium 2009, 2010, 2015; see also Chap. 8 in this volume). New arrivals reached 715 people in 2010 and 1025 people in 2012 (Eurostat 2014). In Sweden, 517 immigrants born in Greece arrived in 2009, followed by 602 in 2010, 1018 in 2011, 1546 in 2012, 1519 in 2013 and 1243 in 2014). The number of Greek citizens arriving in Sweden during the same period was somewhat lower but displayed the same trends (483 in 2009, 520 in 2010, 929 in 2011, 1348 in 2012, 1378 in 2013, 1088 in 2014) (Statistiska Centralbyran 2015). Similar trends were also observed in France, where the number of foreigners of Greek citizenship resident in France (étrangers) increased from 5884 people in 2006 to 5962 in 2008 to 6596 in 2011 (INSEE 2006, 2008, 2011 - later data do not include Greeks as a separate category).

Finally, when it comes to western European destinations outside of the European Union, Switzerland also documents increases in the number of foreign-born Greek citizens present in the country in recent years. The inward migration of Greek citizens increased from 713 persons in 2009 to peak at 1685 incomers in 2013 with a decrease to 1464 persons in 2014 (Statistik Schweiz 2015).

On the basis of the data presented above, it becomes clear that Greek emigration to central and northern Europe is, generally, on the increase since 2008. However, the size and pace of the movement may differ greatly from one country of destination to another. When one compares the current flows to the post-war emigration from Greece to Western Europe, one is struck by aspects of continuity (Germany, Belgium and Sweden having been traditional destinations), and change (the UK and the Netherlands). In terms of size, the average gross annual emigration from Greece to Germany for the period is roughly equal to the numbers of current outflows (about 30,000 persons a year; see Fakiolas and King 1996). However, a direct comparison between the two periods is not easily warranted. For instance, it is reasonable to assume that the free movement of people inside the EU and the absence of state-sponsored, heavily monitored, intra-European migration - typical of the postwar period - underestimates the number of Greeks currently moving or residing 
abroad or engaging in seasonal and repeated migration. Free movement of capital and the common currency might also render difficult the measurement of remittances towards Greece from these recent migrants.

A second tentative conclusion is that the overall number of Greek emigrants does not correspond to a wave of mass emigration, despite the heavy recession and the favorable institutional framework of freedom of movement within the EU. In this regard, Greece does not differ from the other EU member-states that have been severely hit by the crisis. As noted recently, "if we consider the extent, the duration and the harshness of the crisis it seems that a surprisingly lower number of Greeks, Italians, Irish, Spaniards and Portuguese have emigrated than would have been expected" (Gropas and Triandafyllidou 2014a: 5).

There exist many explanations behind the discrepancy between predicted economic migration and observed reality. First, there are well-known impediments to labour mobility within the EU: inter alia, linguistic barriers, cultural differences, inadequate information on labour supply and demand in other EU member-states and incomplete recognition of qualifications (Deutsche Bank Research 2011). Mobility is also, generally, very costly for unskilled workers, who would have the greatest incentive to migrate, while skilled workers are able to cover such costs more easily but do not face as high unemployment levels (for a similar analysis, see SER 2001: 7-8). Htouris (2012) has also underlined the protective role of the Greek family for those hit by the economic crisis in the absence of other welfare provisions. We may assume that this family-based safety net, bolstered by the relative protection of pensions during the crisis, constrains the geographic mobility of young, unemployed Greeks.

An underdeveloped area of research relates to the qualitative characteristics of recent emigrants, such as their skills, professional aspirations, geographic origin, family history and networks etc. Empirical research on emigration is limited in the Greek scholarly community, since most academics and research institutions still focus on issues of immigration (including irregular immigration), settlement, and integration of third-country nationals. Two surveys have dealt exclusively with documenting the characteristics of emigration flows (Lambrianidis 2011; Gropas and Triandafyllidou 2014a, b). However, both concentrated on the movement of the high-skilled, while the older survey is based on data collected prior to the economic crisis.

There is practically no systematic data available on emigration flows of the lower-skilled or unskilled Greek emigration. Due to its seasonal and undocumented nature this type of emigration is also underestimated in official registries (unlike Portugal, there is no recording of posted workers, see Chap. 5 in this volume). This remains an empirical challenge for the full appreciation of the recent migration movement from the South. Indeed, a private communication of the authors with a representative of the Association of Immigrants and Coethnics from Germany, confirmed that many low-skilled workers migrate for a brief period and work in restaurants, construction and transportation (often in businesses owned by relatives or other co-ethnics) without registering residence or employment (telephone interview 10/08/2014). 
In reality, the only piece of empirical research that conveys parts of the bigger picture is the recent online survey by Gropas and Triandafyllidou (2014b). The survey collected responses from 919 Greek citizens who emigrated abroad between 2007 and 2013, the vast majority among them having left since 2009. Biases associated with snowball sampling and self-selection limit the generalizability of the study, but certain conclusions merit discussion. Of all respondents, $88 \%$ hold a higher education degree and $97 \%$ were up to 45 years of age (48\% were under 30 years old). Their five most popular destinations in the EU were the UK, Germany, the Netherlands, Belgium and Sweden, with Switzerland and Norway among the top-five destinations outside the EU (other countries included the United States, United Arab Emirates and Canada).

In the country of destination, most respondents found employment in the IT sector, education and research, medical and paramedical professions, hotel services and catering, and engineering. The wish to improve their academic and professional training, their sense of lacking a future in Greece, and the ability to find better professional opportunities were by far the three most important motivations for leaving abroad. Finally, the majority of their respondents $(58 \%)$ declared their wish to remain in their country of destination for more than 5 years or even migrate further to another country rather than return to Greece in the near future (Gropas and Triandafyllidou 2014b).

The survey dovetails Lambrianidis' findings (2011) based on data collected prior to the outbreak of the crisis, which shows that the phenomenon of Greek emigration of the high-skilled pre-dated the recession. The crisis has only intensified the phenomenon but not to the point of creating a "mass wave" of Greek emigration of professionals and scientists.

\subsection{Public Discourses and Policy Responses on New Migration}

As noted in the previous section, the historical experience of mass postwar emigration into Northern Europe was dominated by the image of the low-skilled male manual worker, typically from rural areas, who sent remittances to the family home, relied on state-led programs of employment and integration and was willing to repatriate once economic conditions were no longer propitious. This image was not entirely accurate, as later migrants in the postwar boom included families and older people, their duration of stay increased and they exploited migrant networks (Glytsos and Katseli 2005). However, the differences with current outflows cannot be overstated: the Greek state has not developed any systematic policy on sending migrants or attracting them back to Greece - the high-skilled exploit professional networks, while the low-skilled rely on family acquaintances. Elite discourse on migration has largely focused on the prospects of "brain drain" but has mostly been framed in terms of individual decision-making. 


\subsubsection{Discourse on New Migration}

The recent movement towards the European North has featured in Greek public discourse mainly in association with the prolonged economic crisis. Since the latter has resulted in acute political polarization, references to the migratory waves are often tinged with partisan interpretations. For instance, when reporting on the so called "neo-immigrants" (neometastates), the Left-leaning press emphasizes themes of appropriation of added value by Northern European employers and exploitation by fraudulent employment offices set up in countries of destination (Avgi 12/05/2013; Eleftherotipia 05/01/2014). On the other side of the political spectrum, the popular right-wing press has evoked romantic, organic images of "national bleeding" and lamented the forceful recruiting of young Greeks by Germany, reminiscent of the forceful recruitment of Jenissaries (paidomazoma) in Ottoman times (Dimokratia 06/09/2012, 04/07/2013). In both cases, the interpretative frames implicitly or explicitly assign responsibility to the choices of pro-austerity governments (often explicitly using terms such as "sell-outs", "traitors"); the same narratives often suggest a conscious and coordinated attempt of Northern European governments to draw the best talent from the South that goes unchallenged. Interestingly, the same reports draw abundantly from historical analogies (a typical one is "Gastarbeiter with a university degree").

Other newspapers, typically less critical of the bailout agreements with EU partners, are concerned with high-skilled migration and the prospect of "brain drain". They emphasize the benefits of migration for educated Greeks who cannot find adequate employment at home, but underline the paradox of aiming to rebuild an economy without its best-skilled workers. Reporting is otherwise full of informal interviews of Greek doctors, nurses and engineers who have moved abroad (To Vima 01/03/2013, Kathimerini 12/01/2013). Journalists often include data from the above-cited studies by Triandafyllidou, Groppa and Lambrianidis (and sometimes briefly interview the authors) to underline the high skills of migrants, as well as the continuities from pre-crisis migration. However, they underreport examples of seasonal, low-skilled migration, with scattered accounts of exploitative working conditions (Kathimerini 28/12/2014). Another notable underreported story in the Greek press is the remarkable outflow of third-country nationals, especially Albanians. An exception was the investigative hourly broadcast by journalist Stavros Theodorakis on Greek-born and raised teenagers who left Greece with their families.

Beyond the press, the new migratory waves are the object of discussions and debates among academics, journalists and political elites. This discussion has at times taken the form of academic roundtables -notably in collaboration with the Greek-German Cultural Society "Dialogos" in Thessaloniki or under the auspices of the Onassis Foundation in Athens- and has at times assumed a debate-style form of "Should I stay or should I go?". One of these debates, organized by Intelligence Squared Greece, featured famous Greek academics, writers and entrepreneurs. Generally, framing migration as a moral dilemma in times of national emergency is of limited consequence in the Greek public discourse, as most arguments are actually about the costs and benefits of the decision to migrate. 
Public discourse regarding outward migration is also notable for its silences. First, it is entirely disconnected from the very heated discussion on third-country nationals residing in Greece, notably immigrants/refugees and asylum seekers whose applications are processed by Greek authorities and who remain in quasilegal or illegal status. The most direct reference to the dangers of anti-immigrant sentiment in Greece backfiring against the Greek new immigrants abroad was made inside the Greek parliament by the Communist Party's MP, Georgios Marinos (Parliamentary Proceedings 15/03/2014). Second, the absence from the public debate of acting Greek associations and representatives of the Greek Orthodox Church in Northern Europe is notable. Time will show if these older organizations have not made public contributions, because arrivals have been very recent or because these particular ethnic associations, created in the 1960s and serving Greek guest workers and their families, represent an outdated form of community organization.

\subsubsection{Policy Initiatives for the New Migrants}

Historically, Greek policymakers have had an ambivalent attitude towards migration into Northern Europe, on the one hand regarding it as a safety valve and a source of income through remittances, and on the other hand bemoaning the skills and talent lost in the process. This was reflected in somewhat contradictory policies: Greek governments initially encouraged remittances and signed bilateral agreements for enhancing workers' assimilation through skills and language training; since the early 1970 s, however, they actively sought repatriation by providing incentives for asset purchases in Greece and reductions in duties and taxes for imported consumer durables (for instance, cars bought abroad). In another example of incoherent policy, the children of Greek migrants were offered the option to attend exclusively Greek schools, but were later encouraged to attend German schools or bilingual programs (Glytsos and Katseli 2005).

If the previous Northward migration wave was anchored to formalized interstate agreements, current movement takes place within a free-movement framework. Migratory trajectories of those leaving Greece are individually decided and executed and inter-state initiatives are of limited importance. For instance, the "Job of My Life" (Mobi-proEU) program, sponsored by the German Federal Ministry of Labor and aimed at training young workers from other EU countries, received very little attention in Greece, mostly because of limited cooperation between the program organizers and the Greek Manpower Employment Organizations-OAED (Greek Reporter 30/01/2014). Certain initiatives promoting partnerships at the municipal level under the auspices of the Greek-German Assembly have also had very limited success on employment and training. On the other hand, sector-specific information sessions and cooperative initiatives among academic institutions in Greece, businesses and professional associations, especially for doctors and 
engineers, were more successful and facilitated the resettlement of thousands of Greek professionals (Kathimerini 13/05/2012, APE-MPE 28/05/2014).

Inversely, there have been no specific laws passed by the Greek parliament or decisions by Greek governments since 2008 targeting recent migrants beyond the provisions of existing EU Treaties. Much like the Greek press, parliamentary debates around the "brain drain" have been subsumed under the pro- and anti- memorandum narratives. New migration is thus used as an off-handed reference in discussions about funding a new technology hub in Thessaloniki or passing the annual budget law (Parliamentary Proceedings 21/08/2013, 05/07/2012). Developments in two policy areas related to the new migrants reveal, if anything, a disengagement of the authorities. First, Parliament passed a law in late 2011 to gradually close or convert Greek-language schools abroad, stressing the need to integrate with hostcountry curriculum. In addition, there has been no progress on the issue of voting rights of Greek citizens residing abroad. Greece is indeed one of the very few European states not to have provisions for expatriates exercising their right to vote (Lafleur 2013) and that despite Constitutional provisions to that effect (Sitaropoulos and Giakoumopoulos v. Greece 2012).

The absence of an official policy towards recent migrants also reflects the absence of an institutionalized framework towards the Greek diaspora, in contrast with other Southern European countries, such as Italy or Portugal. The Council of Expatriate Greeks (Simvoulio Apodimou Ellinismou), founded in 1995 to consult the Greek government on issues pertaining to citizens abroad, had entered a period of decline long before the crisis had started and was virtually inactive by 2010. In fact, the only systematic policy initiative affecting new migrants was the obligation to register at a newfound tax division for Greek citizens living abroad, intended to avoid tax evasion.

\subsection{Conclusion}

Unsurprisingly, the serious economic problems Greece has faced in the last few years have increased migratory outflows and transformed it into a country of emigration - a position it had not assumed in decades. Although the bulk of outflows consist of third-country nationals returning to their home countries or moving to more promising destinations within the European Union, Greeks, especially the high-skilled, have also emigrated or postponed repatriation. They have chosen historically preferred destinations (with Germany assuming the lion's share), as well as more novel ones, such as the UK. However, this movement has not assumed the massive proportions of post-war migration, as the severity of the crisis might have suggested and the heavy -if rather superficial- politicization of the "brain drain" implied. On the other hand, existing migrant networks and institutionalized support by the Greek authorities have proven ill-suited, under-developed and under-utilized to face the needs of the new migrants, again in contrast with the more structured post-war migration. In fact, policy and opinion makers in Greece have mostly 
subsumed the importance and challenges of recent movements under domestic political divisions. It remains to be seen if concrete policy changes vis-à-vis recent migrants materialize, as Greece enters a post-crisis era.

\section{References}

Avgi. (2013, May 12). Gastarbaiter me Ptichio; (2014, January 22) Thimata Ekmetalleusis oi Ellines Neo-Metanastes.

Balourdos, D. (2012). 'I Ftohia stin Ellada: Taseis, prokliseis kai prooptikes' In: D. Balourdos \& M. Petraki (Ed.), Nea Ftoheia kai Koinonikos Apokleismos. Politikes Katapolemisis kai Kathierosi enos Elahistou Eggyimenou Eisodimatos (pp. 21-53), Special Meeting of the Permanent Committee on Social Affairs, 13th Period - 3rd Term, Athens: Hellenic Parliament.

CBS - Centraal Bureau voor de Statistik. (2014). Population: Dex, age, origin and generation. https://www.cbs.nl/. Accessed 28 Sept 2015.

Deutsche Bank Research. (2011). Labour mobility in the euro area. Reports on European integration EU monitor No. 85. Frankfurt am Main.

Dimokratia. (2012, September 6) Ethniki Aimorragia; 2013, July 4, To Germaniko Paidomazoma ston Exathliomeno Noto.

Eleftherotipia. (2014, January 5). I Ellada ksanapligoni ta paidia tis.

Elstat. (2009). Deltio Typou. Ereyna ergatikou dynamikou A' trimino 2009, Pireaus, 22 June 2009.

Elstat. (2010). Deltio Typou. Ereyna ergatikou dynamikou A' trimino 2010, Pireaus, 17 June 2010.

Elstat. (2011). Deltio Typou. Ereyna ergatikou dynamikou A' trimino 2011, Pireaus, 16 June 2011.

Elstat. (2012). Deltio Typou. Ereyna ergatikou dynamikou A' trimino 2012, Pireaus, 14 June 2012.

Elstat. (2013a). Unemployment, long-term and short-term unemployed. 8 October 2013.

Elstat. (2013b). Deltio Typou. Ereyna ergatikou dynamikou A' trimino 2013, Pireaus, 13 June 2013.

Elstat. (2014). Deltio Typou. Ereyna ergatikou dynamikou A' trimino 2014, Pireaus, 12 June 2014.

Elstat. (2015). Deltio Typou. Ereyna ergatikou dynamikou A' trimino 2015, Pireaus, 11 June 2015.

Eurostat. (2013a). Income pooling and equal sharing within the household - what can we learn from the 2010 EU-SILC module? Eurostat Methodologies and Working Papers.

Eurostat. (2013b). Crude rate of net migration plus adjustment. Accessed 7 July 2014.

Eurostat. (2014). Immigration by sex, age group and citizenship, Brussels, 20 June 2014. http:// epp.eurostat.ec.europa.eu. Accessed 10 July 2014.

Eurostat. (2015a). Real GDP growth rate - Volume. http://epp.eurostat.ec.europa.eu. Accessed 28 Sept 2015.

Eurostat. (2015b). GDP per capita in PPS. http://epp.eurostat.ec.europa.eu. Accessed 28 Sept 2015.

Eurostat. (2015c). Population on 1 January. http://epp.eurostat.ec.europa.eu. Accessed 28 Sept 2015.

Eurostat. (2015d). Mean and median income by age and sex. http://epp.eurostat.ec.europa.eu. Acccessed 28 Sept 2015.

Fakiolas, R., \& King, R. (1996). Emigration, return, immigration: A review and evaluation of Greece's postwar experience of international migration. International Journal of Population Geography, 2, 171-190.

Glytsos, N. P., \& Katseli, L. T. (2005). Greek migration: The two faces of Janus. In K. Zimmermann (Ed.), European migration: What do we know? (pp. 337-388). Oxford: Oxford University Press.

Greek Reporter. (2014, January 30). MobiPro-EU: The job of my life. 
Gropas, R., \& Triandafyllidou A. (2014a). Emigrating in times of crisis. Highlights and new data from an e-survey on high-skilled emigrants from southern Europe and Ireland. Survey Report, Global Governance Programme, European University Institute.

Gropas, R., \& Triandafyllidou, A. (2014b). Country focus: Emigration of Greek nationals during the crisis. Florence: European University Institute.

Htouris, S. (2012). Oi diastaseis tis Ftohias kai tou Koinonikou Apokleismou stin Elliniki Neolaia. Politikes gia ti metavasi apo tin ekpaideysi sthn apasholisi kai tin epaggelmatiki zoi, in Balourdos D. \& Petraki M. (Ed.), Nea Ftoheia kai Koinonikos Apokleismos. Politikes Katapolemisis kai Kathierosi enos Elahistou Eggyimenou Eisodimatos (pp. 85-97). Special Meeting of the Permanent Committee on Social Affairs, 13th Period - 3rd Term, Athens: Hellenic Parliament.

INSEE. (2006). Entragers selon le sexe, la categorie de population et la nationalite detaillee, Recensement de la population 2006, 2008, 2011 exploitation principale, MORE (full details).

INSTAT \& IMO. (2014). Return migration and integration in Albania 2013.

OECD International Migration Outlook. (2013). http://www.keepeek.com/Digital-AssetManagement/oecd/social-issues-migration-health/international-migration-outlook-2013 migr_outlook-2013-en. Accessed 5 July 2014.

OECD International Migration Outlook. (2015). http://www.keepeek.com/Digital-AssetManagement/oecd/social-issues-migration-health/international-migration-outlook-2015_ migr_outlook-2015-en. Accessed 28 Sept 2015.

Karakitsios, A. (2014). Ftohia ton ergazomenon stin Ellada: Diastaseis kai Politikes. Keimeno Politikis 23, July 2014. Athens: ELIAMEP.

Kasimis, C. (2013). Greece, migration 1830s to present. In E. Ness (Ed.), The Encyclopedia of global human migration. London: Blackwell Publishing.

Kathimerini. (2014, December 28). Thimata Ekmetallefsis i Neometanastes; (2013, January 12). Sti Germania 123,000 Ellines Metanastes; (2012, May 13) 6,000 Ellines Giatroi sti Germania.

Lafleur, J. M. (2013). Transnational politics and the state: The external voting rights of diasporas. Abingdon: Routledge.

Lambrianidis, L. (2011). Ependiontas sti figi: i diarroi epistimonon apo tin Ellada tin epohi tis pagkosmiopoiisis. Athens: Kritiki.

Matsaganis, M. (2013). I politiki kata tis ftohias stin Ellada tis krisis (Group of Public Policy Analysis Bouletin 6/2013). Athens: Kritiki.

Matsaganis, M., \& Leventi, C. (2013). I anatomia tis ftohias stin Ellada tou 2013 (Group of Public Policy Analysis Bouletin 5/2013). Athens: Kritiki.

Office of National Statistics. (2015). Population by country of birth and nationality reports, 20092015. https://www.ons.gov.uk/. Accessed 29 Sept 2015.

Parliamentary Proceedings (Praktika Olomeleias). http://www.hellenicparliament.gr/Praktika/ EvretiriaEpisimonPraktikonOlomeleias. Accessed 6 July 2014.

SER - Sociaal-Economische Raad. (2001). Labour mobility in the European Union, Abstract 01/04E, The Haag. http://www.ser.nl/en/ /media/ba46626b4f6645d8b57651c835da2be1.ashx. Accessed 30 July 2014.

Statistics Belgium. (2009). Bevolking per nationaliteit, geslacht, leeftijdsgroepen op 1/1/2009. http://statbel.fgov.be. Accessed 10 July 2014.

Statistics Belgium. (2010). Bevolking per nationaliteit, geslacht, leeftijdsgroepen op 1/1/201 http://statbel.fgov.be/ Accessed 10 July 2014.

Statistics Belgium. (2015). Bevolking per nationaliteit, geslacht, leeftijdsgroepen op 1/1/2015. http://statbel.fgov.be. Accessed 29 Sept 2015.

Statistik Austria. (2013). Wanderungsstatistik 2012 Inkl. Revision seit 2007, Wien: Bundesanstalt Statistik Österreich, January 2014. http://www.statistik.at/web_en/statistics/population/migration/index.html. Accessed 10 July 2014.

Statistik Schweiz - Bundesamt für Statistik. (2015). Ständige und nichtständige Wohnbevölkerung nach institutionellen Gliederungen,Geburtsort und Staatsangehörigkeit. http://www.pxweb. bfs.admin.ch/. Accessed 29 Sept 2015. 
Statistisches Bundesamt. (2014). Bevölkerung und Erwerbstätigkeit. Vorläufige Wanderungsergebnisse 2013, Wiesbaden, 22 May 2014. https://www.destatis.de/. Accessed 10 July 2014.

Statistiska Centralbyran. (2015). Immigrations and emigrations by country of birth and sex. Year 2000-2014, Stockholm. http://www.statistikdatabasen.scb.se/. Accessed 28 Sept 2015.

To Vima. (2013, March 1). 'Germania: H Elit ton Ergazomenon sto Deftero Revma Metanastefsis'. Triandafyllidou, A., \& Gropas, R. (2014). "Voting with their Feet": Highly skilled emigrants from Southern Europe. American Behavioral Scientist, 58(12), 1614-1633.

Zografakis, S., \& Mitrakos Th. (2012). 'O kindynos hamilou eisodimatos sti diarkeia tis trehousas krisis: I apantisi tou elahistou eggyimenou eisodimatos'. In Balourdos D. \& Petraki M. (Eds), Nea Ftoheia kai Koinonikos Apokleismos. Politikes Katapolemisis kai Kathierosi enos Elahistou Eggyimenou Eisodimatos (pp 55-83) Special Meeting of the Permanent Committee on Social Affairs, 13th Period - 3rd Term, Athens: Hellenic Parliament.

Open Access This chapter is licensed under the terms of the Creative Commons AttributionNonCommercial 2.5 License (http://creativecommons.org/licenses/by-nc/2.5/), which permits any noncommercial use, sharing, adaptation, distribution and reproduction in any medium or format, as long as you give appropriate credit to the original author(s) and the source, provide a link to the Creative Commons license and indicate if changes were made.

The images or other third party material in this chapter are included in the chapter's Creative Commons license, unless indicated otherwise in a credit line to the material. If material is not included in the chapter's Creative Commons license and your intended use is not permitted by statutory regulation or exceeds the permitted use, you will need to obtain permission directly from the copyright holder.

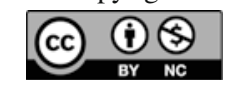

